\title{
An investigation of micronucleus and mutation induction by oxazepam in mammalian cells
}

\author{
Helga Stopper, Carsten Körber, Diane L.Spencer ${ }^{1}$, \\ Stephan Kirchner, William J.Caspary ${ }^{1}$ and \\ Dietmar Schiffmann ${ }^{2}$
}

Institute of Pharmacology and Toxicology, University of Würzburg, W-8700 Würzburg, FRG, 'Laboratory of Environmental Carcinogenesis and Mutagenesis, National Institute of Environmental Health Sciences, National Institutes of Health, Research Triangle Park, NC 27709, USA and 'Instiute of Animal Physiology, Cytopathophysiology Unit, University of Rostock. 0-2500 Rostock, FRG

The benzodiazepines are a class of drugs that are widely used in the treatment of various psychiatric disorders. One member of this class, oxazepam, is also a common metabolite of several other benzodiazepines. Since the evidence for the genetic toxicity and carcinogenic properties of these compounds is inconsistent, we investigated the oxazepam-induced formation of micronuclei in Syrian Hamster embryo fibroblast (SHE) cells, human amniotic fluid fibroblast-like (AFFL) cells and L5178Y mouse cells. A dose-dependent increase in micronucleus fractions was found in all three cell lines. The time course of micronucleus induction in $\mathbf{L S 1 7 8 Y}$ cells showed a maximum at $5 \mathrm{~h}$ after treatment, suggesting that the micronuclei were formed in the first mitosis after treatment. Kinetochore staining (CREST-antiserum) revealed the presence of kinetochores in $-50 \%$ of the micronuclei in all three cell types. This result was further confirmed by in situ hybridization in $\mathbf{L S 1 7 8 Y}$ cells and indicates the presence of whole chromosomes or centric fragments as well as acentric fragments in the oxazepam-induced micronuclei. The L5178Y cells did not show a mutagenic response to oxazepam at any of the doses or expression times used.

\section{Introduction}

Benzodiazepines make up a class of drugs that are widely used in the treatment of various psychiatric disorders. One member of this class, oxazepam (Figure 1), is a common metabolite of several benzodiazepines. An epidemiological study suggested an association between increased breast cancer and use of benzodiazepines in women (Stoll, 1976). However, this association was later discounted (Kleinerman et al., 1984). Although there are many reports of fetotoxic and teratogenic effects in animals (for review, see Tucker, 1985), benzodiazepines have been used to treat psychiatric complications of pregnancy (Shannon et al., 1972; Kanto, 1982). There have also been reports of increases in severe congenital abnormalities in infants whose mothers took such benzodiazepines as oxazepam during pregnancy (Milkovich and van den Berg, 1974; Laegreid et al., 1989); however, reports to the contrary have also been published (Hartz et al., 1975).

A number of rodent studies on the carcinogenicity of benzodiazepines have been performed. Induction of tumors was reported by Fox and Lahcen (1974; Swiss Webster mice), de la Iglesia (1981; CF1 mice and Wistar rats) and Robinson et al. (1984; CRCD rats and CRCD-1 mice). In a study on promotion, Remandet et al. (1984) found no evidence of increases in liver neoplasms or enzyme altered foci with benzodiazepines in F344 rats. Preat et al. (1987) reported that oxazepam possessed promotional activity in Wistar rats in two different assays for hepatocarcinogenesis. Diwan et al. (1986) found diazepam and oxazepam to be promotors of initiated liver tumors in mice. Recently, the National Toxicology Program reported clear evidence for increases in hepatocellular adenomas and carcinomas in both sexes of the B6C3F1 and Swiss Websier nuvuse, and increased hepatoblastomas in B6C3F1 mice (NTP, 1993).

After in vivo application, the most extensively studied benzodiazepine, diazepam, induced micronuclei in erythrocytes (and nucleated cells) from mouse bone marrow (Das and Kar, 1986). However, in other studies, it did not induce chromosomal aberrations in bone marrow cells from the mouse (Miller and Adler, 1989; Xu and Adler, 1990), the Chinese hamster (Schmid and Staiger, 1969) or the Sprague-Dawley rat (Ishimura et al., 1975). Adler et al. (1991) could not find any evidence that diazepam induced micronuclei in erythrocytes from mouse bone marrow in vivo. In addition, no increased sister chromatid exchanges or chromosomal aberrations were observed in the lymphocytes of treated patients (Torigoe, 1979; Husum et al., 1985). Diazepam also induced micronuclei in several cell systems in vitro. The compound produced a significant increase in frequency of CREST positive micronuclei in CI-1 Chinese hamster cells (Antoccia et al., 1991) as well as in human fibroblasts and V79 Chinese hamster cells (Bonatti et al., 1992). Lafi and Parry (1988) showed that diazepam induced chromosomal aberrations in cultured Chinese hamster cells. This result was not supported in three other studies (Ishidate et al., 1978; Matsuoka et al., 1979; NTP, 1993) in which no evidence of diazepam-induced chromosomal aberrations in Chinese hamster cells was found. Other in vitro effects include mitotic arrest in human fibroblast which were induced not by affecting the microtubules but by inhibiting the separation of centrioles (Andersson et al., 1981), as well as mitotic arrest, multipolar spindles, lagging chromosomes and aneuploidy (Hsu et al., 1983), and disruption of mitosis with concomitant chromosome loss in Chinese hamster cells (Parry et al., 1986; Lafi et al., 1987). Results of tests for induction of chromosomal aberrations and sister chromatid exchange in human fibroblasts (Staiger, 1969; Kawachi et al., 1980; Sasaki et al., 1980) or lymphocytes (Staiger, 1970; Zhurkov, 1975) in vitro were negative.

There are contradictory reports on the mutagenic activity of<smiles>CCCCCC1=NC(O)C(=O)Nc2ccc(Cl)cc21</smiles>

Ftg. 1. Chemical structure of oxazepam. 
oxazepam. The compound was found mutagenic in Salmonella strains TA100 and TA98 with metabolic activation (Batzinger et al., 1978). Balbi et al. (1980) found no evidence for mutagenic activity of oxazepam in these strains as well as in TA1535 and 37 , with and without metabolic activation.

The clear neoplastic response of B6C3F1 and Swiss Webster mouse livers to oxazepam (NTP, 1993) led us to investigate genetic toxicity endpoints that could perhaps elucidate possible mechanisms leading to this response. B6C3Fl mice typically develop a relatively high incidence of hepatic neoplasia and the application of this endpoint to predict carcinogenicity in humans is controversial.

In view of the widespread use of benzodiazepine medication, especially in children and during pregnancy, and the inconsistent results on the genetic toxicity of these compounds in vitro and in viwo, we investigated the ability of oxazepam to induce mutations at the $t k$ locus of L5178Y mouse lymphoma cells and to induce micronuclei in L5178Y cells, Syrian hamster embryo fibroblast (SHE) cells and human amniotic fluid fibroblast-like (AFFL) cells. We further investigated the contents of the induced micronuclei by anti-kinetochore immunofluorescence staining as well as in situ hybridization.

\section{Materials and methods}

Chemicals

Bisbenzimide 33258, diethylstilbestrol (DES), ethyl methanesulfonate (EMS), hypoxanthine, methotrexate, oxazepam, thymidine, trifturothymidine (TFT) and FITC-conjugated goat anti-human antibody were purchased from Sigma Chemie GmbH (Deisenhofen, FRG). Dimethyl-sulfoxide (DMSO) and formamide were acquired from Aldrich Company Europe (Steinheim, FRG) and CREST-Senum (anti-kinetochore antibody) was purchased from Antibodies Inc. (Davis, CA). Digoxigenin and the anti-digoxigenin detection system were acquired from Boehringer (Mannheim, Germany).

Cell culture

Mouse L5178Y cells, clone 3.7.2c (Clive, 1972), were used for micronucleus assays (including kinetochore analysis and in situ hybridization) and mutation assays. They were cultured in suspension in RPMI 1640 supplemented with $95 \mathrm{U} / \mathrm{ml}$ penicillin, $95 \mu \mathrm{g} / \mathrm{ml}$ streptomycin, $0.25 \mathrm{mg} / \mathrm{ml} \mathrm{L}$-glutamine, $107 \mu \mathrm{g} / \mathrm{ml}$ sodium pyruvate and $10 \%$ heat-inactivated horse serum (Sigma). Cell cultures were grown in a humidified atmosphere with $5 \% \mathrm{CO}_{2}$ in air at $37^{\circ} \mathrm{C}$. SHE cells were used for micromucleus assays (including kinetochore analysis). They were established as described previously (Schiffmann et ah, 1984). All experiments were performed with tertiary or quarternary cultures derived from 13 day old Syrian hamster embryos. The culare medium used was IBR-modified Dulbecco's reinforced medium (Gibco, Grand Island, NY), supplemented with $100 \mathrm{U} / \mathrm{mL}$ penicillin, $100 \mu \mathrm{g} / \mathrm{ml}$ streptomycin, $3.7 \mathrm{~g} / \mathrm{NaHCO}_{3}$ and $15 \%$ fetal calf serum (Gibco, Eggenstein, FRG). Cell cultures were grown in a humidified atmosphere with $12 \% \mathrm{CO}_{2}$ in air at $37^{\circ} \mathrm{C}$. AFFL cells (Hoehn and Salk, 1982) were used for micronucleus assays (including kinetochore analysis). They were taken from a mid-trimester pregnancy and cultured in DMEM medium supplemented with $100 \mathrm{U} / \mathrm{ml}$ penicillin, $100 \mathrm{\mu g} / \mathrm{ml}$ streptomycin, $3.7 \mathrm{~g} / \mathrm{NaHCO}_{3}$ and $10 \%$ FCS (Gibco, Eggenstein, FRG). Cell cultures were grown in a humidified atmosphere with $5 \% \mathrm{CO}_{2}$ in air at $37^{\circ} \mathrm{C}$.

In vitro micronucleus assay and kinetochore analysis

Treatment time was varied according to the different cell cycle durations of the cell lines used. For recovery in dose-response experiments, a time was chosen that only allowed one mitosis between treatment and fixation. Exponentially growing mouse LS178Y cells (cell cycle duration $10 \mathrm{~h}$ ) were treatod with oxazepam for $4 \mathrm{~h}$. The vehicle control was 1\% DMSO. After removing the chemicals by centrifugation and medium replacement, the cells were incubated for $5 \mathrm{~h}$ for dose-response experiments or for $0-25 \mathrm{~h}$ for time course experiments. The cells were then brought onto glass slides by cytospin centrifugation. Fixation was performed with methanol $\left(-20^{\circ} \mathrm{C}, 1 \mathrm{~h}\right)$. SHE cells (cell cycle duration $16 \mathrm{~h}$ ) were grown in culaure flasks to medium density and treated for $5 \mathrm{~h}$ with oxazepam (dissolved in DMSO) or DMSO for $5 \mathrm{~h}$. The final concentration of DMSO did not exceed $1 \%$. After removing the chemicals by medium replacement the cells were incubated for $12 \mathrm{~h}$. At that time the cells were trypsinized and brought onto glass slides by cytospin centrifugation. Fixation was performed with methanol $\left(-20^{\circ} \mathrm{C}, 1 \mathrm{~h}\right.$ ). AFFL cells (cell cycle duration $24 \mathrm{~h}$ ) were plated on glass coverslips in $35 \mathrm{~mm}$ Peari dishes and grown to medium density. Then the cell culture medium was replaced by culture medium containing oxazepam (diluted in DMSO) or DMSO (1\%). Following an incubation period of $10 \mathrm{~h}$ the compound was removed by changing the medium. At $12 \mathrm{~h}$ later cells were fixed with methanol $\left(-20^{\circ} \mathrm{C}\right.$, 1 h). For staining of nuclei and micromuclei, the slides or coverslips were washed with distilled water, incubated with bisberzzimide 33258 (1 $\mu \mathrm{g} / \mathrm{ml}$, $5 \mathrm{~min})$, washed three times with distilled water and mounted for microscopy. Kinetochore staining was achieved by incubating the fixed cell preparations (after rinsing with phosphate buffered saline (PBS)] with CREST serum $(60 \mathrm{~min})$ in a humidified chamber at $37^{\circ} \mathrm{C}$. After rinsing with PBS again, the cells were incubated as before with FITC-conjugated goat anti-human antibody (diluted 1:100 in PBS), rinsed again and counterstained with bisbenzimide $33258(1 \mu \mathrm{g} / \mathrm{ml}, 5 \mathrm{~min})$. Using a magnification of $1250 \times$ the number of nuclei and micronuclei were scored. Exch data point represents the mean of three slides with 2000 nuclet evaluated per slide. The synthetic estrogen DES was used to illustrate the effects of an aneugen.

\section{In situ hybridization}

Mouse L5178Y cells were centrifuged onto glass slides (cytospin) and dehydrated in an ethanol series $(70,80,95,100 \%, 2 \mathrm{~min}$ each) after fixation in cold methanol:acetic acid $\left(3: 1,-20^{\circ} \mathrm{C}, 30 \mathrm{~min}\right)$. Prior to hybridization slides were immersed in $70 \%$ formamrde $2 \times S S C\left(\mathrm{pH} \mathrm{7.0,2} \mathrm{min}, 70^{\circ} \mathrm{C}\right)$ to denature the DNA. Subsequently, they were again dehydrated as described above. For hybridization, cells were incubated in $50 \%$ formamide $2 \times \mathrm{SSC} / 10 \%$ dextran sulfate, containing $20 \mathrm{ng}$ of digoxigenated DNA probe. A mouse minor satellite probe that binds to or pear to the kinetoctore domain of every mouse chromosome (Wong and Rattner, 1988) was used for detection of centromeric DNA regions in these cells. Hybridization was performed overnight in a humidified $(2 \times$ SSC) chamber at $37^{\circ} \mathrm{C}$. Immunochemical detection was carried out using a fluorescent FTTC - anti-digoxigenin conjugate (Boehringer). Whole DNA was counterstained with bisbenzumide $33258(1 \mu \mathrm{g} / \mathrm{ml}, 5 \mathrm{~min})$ and the slides were evaluated for the presence of centromeric DNA signals in micronucles with fluorescence microscopy.

Mutation assay

Cultures of mouse L5178Y cells were treated with methotrexate before each experiment to kill pre-existing TFT-resistant cells. To accomplish this, cells were incubsted for $24 \mathrm{~h}$ in culture medium plus methotrexate $(0.3 \mu \mathrm{g} / \mathrm{ml})$, thymidine $(9 \mu \mathrm{g} / \mathrm{ml})$, hypoxanthine $(15 \mu \mathrm{g} / \mathrm{ml})$ and glycine $(22.5 \mu \mathrm{g} / \mathrm{ml})$. The cells were then incubated for at least $48 \mathrm{~h}$ in the same medium without methotrexate. To measure chemically induced mutations using the in situ procedure (Rudd et al., 1990; Spencer et al, 1993), duplicate cultures containing $6 \times 10^{6}$ cells in $10 \mathrm{ml}$ medium were treated with DMSO (control) or oxazepam (dissolved in DMSO). EMS $(300 \mu \mathrm{g} / \mathrm{ml})$ was used as a positive control. Incubation was performed for $4 \mathrm{~h}$ in a rotating drum, then the cells were washed twice with fresh medium. From each tested culture. $0.5 \times 10^{6}$ cells were added to $50 \mathrm{ml}$ of semisolid culture medium (containing 0.25\% granulated agar, Baltimore Biological Laboratories, Baltimore, MD) and plated into two plastic $100 \mathrm{~mm}$ culture dishes and allowed to solidify at room temperature. TFT-resistant cells were selected by adding an overlay of TFT (final concentration $8 \mu \mathrm{g} / \mathrm{ml}$ ) in semisolid medium after an appropriate expression time. Cloning efficiency was determined by adding 600 cells to $100 \mathrm{ml}$ of semisolid medium in three $100 \mathrm{~mm}$ culture dishes. All plates were incubated for a total of $11-12$ days at $37^{\circ} \mathrm{C}$ in $5 \% \mathrm{CO}_{2}$ for colony growh. An automatic colony counter was used to coum the number of TFTresistam colonies. The counter detected colonies larger than $0.25-0.3 \mathrm{~mm}$ diameter (Model 982B; Artek Systems, Farmingdale, NY).

\section{Results}

Oxazepam (Figure 1) induced the formation of micronuclei in a dose dependent manner in three different mammalian cell types (Figures 2-5). In mouse L5178Y cells, the micronucleus fraction increased up to a concentration of $200 \mu \mathrm{g} / \mathrm{ml}$ oxazepam (Figure 2). At the next higher dose tested $(250 \mu \mathrm{g} / \mathrm{ml})$, we observed fragmentation of nuclei which made evaluation of cells for micronucleus induction impossible. Oxazepam did not affect Trypan blue exclusion under micronucleus assay conditions up to a concentration of $200 \mu \mathrm{g} / \mathrm{ml}$ (data not shown). In SHE cells, the micronucleus fraction reached a maximum at $100 \mu \mathrm{g} / \mathrm{ml}$ oxazepam and decreased at higher concentrations (Figure 3). In AFFL cells, the micronucleus fraction increased up to a concentration of $250 \mu \mathrm{g} / \mathrm{ml}$ oxazepam (Figure 4). Higher concentrations were not applied, since microscopically visible crystals due to limited solubility of oxazepam appeared in the culture medium at concentration of $200 \mu \mathrm{g} / \mathrm{ml}$ and higher. When we examined the time course of micronucleus induction in 


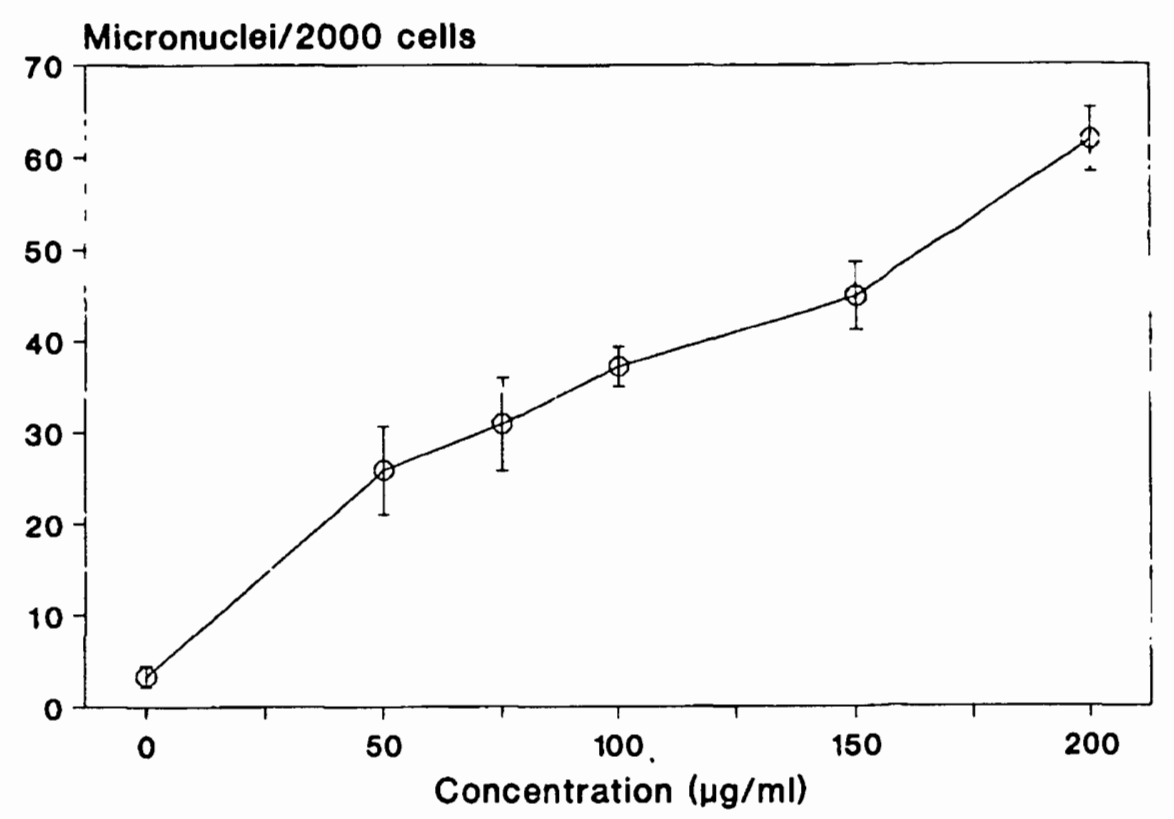

Fig. 2. Induction of micronucleus formation in LS178Y cells. Cells were treated with oxazepam for $4 \mathrm{~h}$ and evaluated $5 \mathrm{~h}$ later.

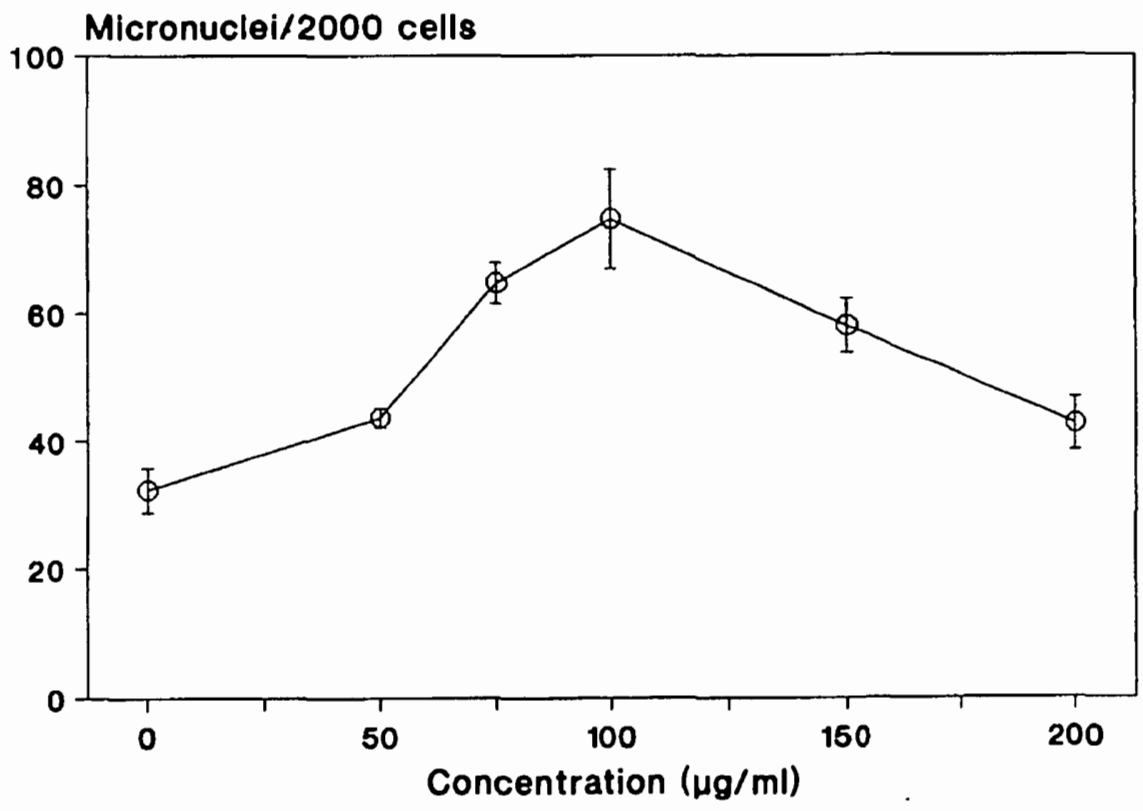

Flg. 3. Induction of micronucleus formation in SHE cells. Cells were treated with oxazepam for $5 \mathrm{~h}$ and evaluated $12 \mathrm{~h}$ later.

L5178Y cells, the fraction of micronuclei was maximal $5 \mathrm{~h}$ after the oxazepam treatment (Figure 5).

Anti-kinetochore staining of micronuclei (Table $\mathrm{D}$ ) revealed that $41-61 \%$ of the oxazepam induced micronuclei in all three cell types contained a signal, compared with $22-42 \%$ in the vehicle controls. The aneugenic compound DES also induced micronuclei and 77-85\% were stainable for kinetochore protein in mouse L5178Y and SHE cells. Kinetochore staining was carried out under optimal conditions which were determined for each cell type and were derived from the dose - response and time course experiments of micronucleus induction and the known cell cycle times (10 h for mouse L5178Y cells, $16 \mathrm{~h}$ for SHE cells and $24 \mathrm{~h}$ for AFFL cells).

The staining of centromeric DNA was achieved by in situ hybridization of mouse L5178Y cells with mouse minor satellite DNA. This DNA binds to the kinetochore region of the chromosomes. After a $4 \mathrm{~h}$ treatment and fixation $5 \mathrm{~h}$ later (Table II), $47 \%$ of the $200 \mu \mathrm{g} / \mathrm{ml}$ oxazepam-induced micronuclei showed a signal, whereas $28 \%$ of the spontaneous micronuclei and $82 \%$ of the $10 \mu \mathrm{g} / \mathrm{ml}$ DES-induced micronuclei contained stainable centromeric DNA.

We examined mouse LS178Y cells for their mutagenic response to oxazepam. This cell line is heterozygous for the thymidine kinase gene and the active allele can be inactivated by mutational events and render the cell resistant to TFT. In the assay used here (Rudd et al., 1990; Spencer et al., 1993) every surviving mutant cell forms a single colony due to cloning in semisolid agar immediately after exposure to the chemical. The 
selecting agent, TFT, is then added after appropriate expression times. The positive control EMS at $300 \mu \mathrm{g} / \mathrm{ml}$ yielded a 9 -fold increase in mutation fraction (Tables III and IV) compared to the vehicle control. However, oxazepam did not show a significant increase in TFT resistance over the vehicle control at any of the doses $(50-200 \mu \mathrm{g} / \mathrm{ml})$ examined (Table III). After different expression times, the positive control EMS $(300 \mu \mathrm{g} / \mathrm{ml})$ showed a time dependent increase in mutation fraction (Table IV), but oxazepam at $200 \mu \mathrm{g} / \mathrm{ml}$ did not show any significant increase.

\section{Discussion}

The benzodiazepine oxazepam induced the formation of micronuclei in the three cell types derived from three different mammalian species: Mouse (L5178Y), Syrian hamster (SHE) and human (AFFL). In mouse L5178Y and AFFL cells, the micronucleus fraction increased linearly with increasing dose up to 200 or $250 \mu \mathrm{g} / \mathrm{ml}$, depending on the cell line used. In SHE cells, a maximum was reached at $100 \mu \mathrm{g} / \mathrm{ml}$ and higher doses resulted in decreased values. This could be due to an increased sensitivity of these cells to irreversibility of cell cycle arrest which would render the cells countable but unable to undergo mitosis and produce micronuclei.

Since the peak in the oxazepam-induced micronucleus fraction occurred $5 \mathrm{~h}$ after treatment, the induction of micronuclei by oxazepam is likely to occur during the course of the first mitosis after treatment. The kinetics of micronucleus induction by oxazepam was similar to the one observed after treatment with

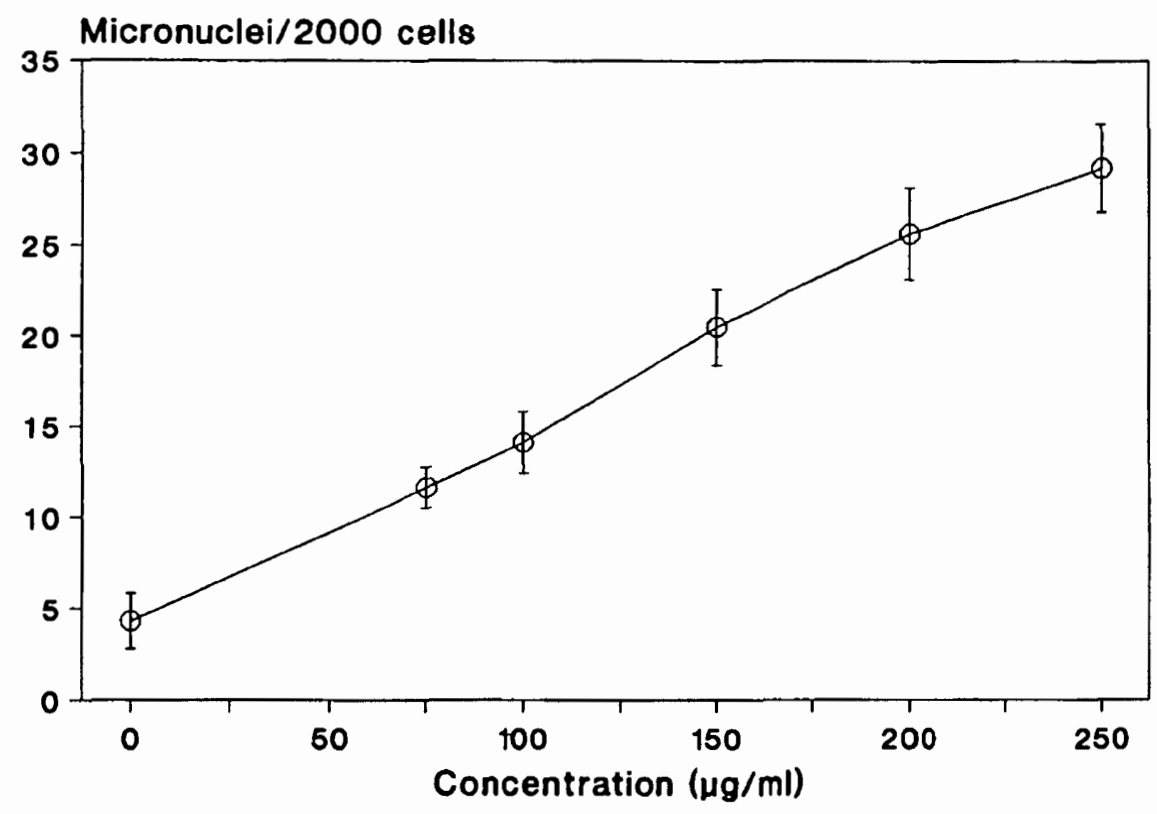

Fig. 4. Induction of micronucleus formation in AFFL cells. Cells were treated with oxazepam for $10 \mathrm{~h}$ and evaluated $12 \mathrm{~h}$ later.

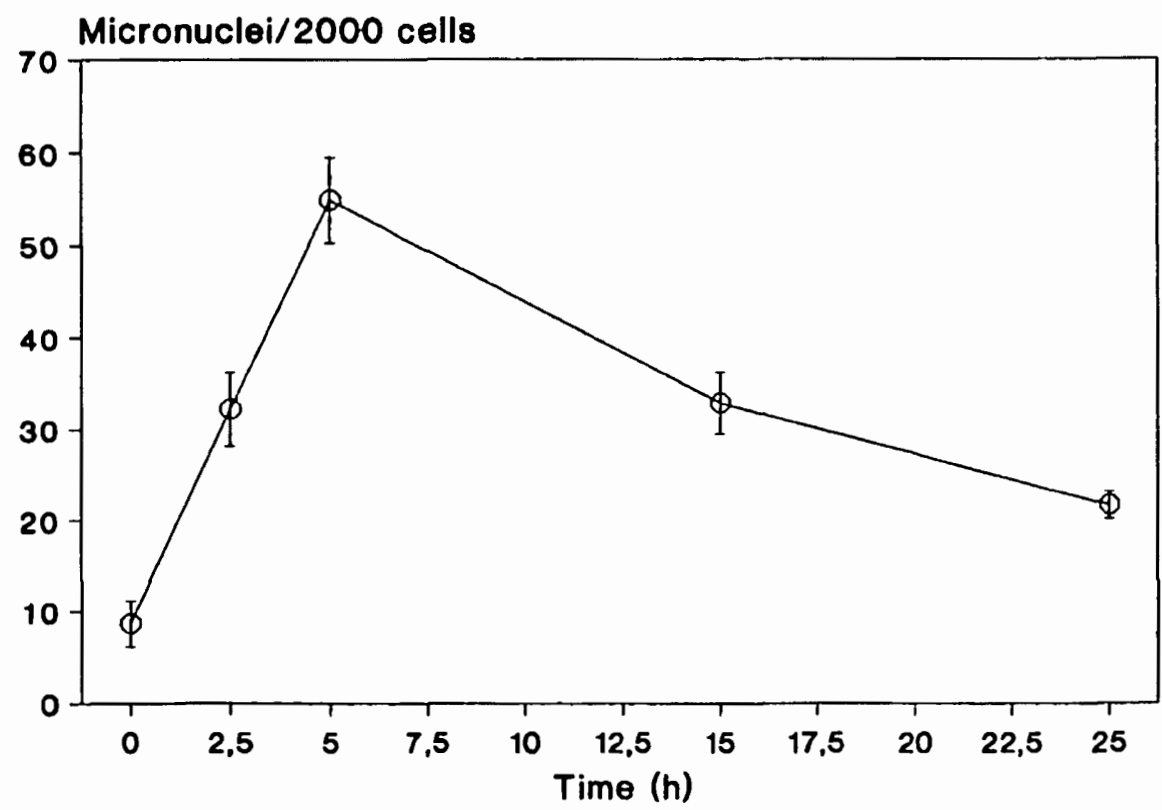

Fig. 5. Time course of micromucleus induction in L5178Y cells. Cells were treated for $4 \mathrm{~h}$ with $200 \mu \mathrm{g} / \mathrm{ml}$ oxazepam and evaluated at the indicaled times after that. The spontaneous (background) micronucleus fraction was $3.32 \pm 1.14$ micronuclei/2000 cells in this experiment. 
the aneuploidy-inducing estrogen DES (H.Stopper et al., manuscript in preparation). The mechanism of micronucleus induction by DES is known to operate during the course of mitosis

Table I. Presence of kinetochores in micronuclei

\begin{tabular}{llll}
\hline Cell type & $\begin{array}{l}\text { Oxazepam } \\
\text { concentration }(\mu \mathrm{g} / \mathrm{ml})\end{array}$ & $\begin{array}{l}\text { No. of evaluated } \\
\text { micronuclei }\end{array}$ & $\mathscr{x}_{\mathrm{K}} \mathrm{K}^{+}$ \\
\hline L5178Y & 0 & 100 & 22 \\
& 200 & 300 & $53 \pm 4.6$ \\
& DES $(10 \mu \mathrm{g} / \mathrm{ml})$ & 300 & $77 \pm 4.2$ \\
AFFL & 0 & 120 & 42 \\
& 200 & 300 & $41 \pm 4.4$ \\
SHE & 0 & $300^{\circ}$ & $23 \pm 7$ \\
& 100 & 120 & 47 \\
& DES $(13.4 \mu \mathrm{g} / \mathrm{ml})$ & $300^{2}$ & $85 \pm 3$ \\
\hline
\end{tabular}

Presence of kinetochores in micronuclei $\left(\mathbf{K}^{+}\right)$of three different cell lines. Experimental conditions: $4 \mathrm{~h}$ treatment and evaluation $5 \mathrm{~b}$ after that for L5178Y cells, $10 \mathrm{~b}$ treatment and evaluation $12 \mathrm{~b}$ after that for human amniotic fluid cells, $5 \mathrm{~h}$ treatment and evaluation $12 \mathrm{~h}$ after that for SHE cells.

'Data taken from Stopper et al. (1992).

\begin{tabular}{llll}
\hline Table II. Presence of centromeric DNA in micronuclei & \\
\hline Compound & $\begin{array}{l}\text { Concentration } \\
(\mu \mathrm{g} / \mathrm{ml})\end{array}$ & $\begin{array}{l}\text { No. of evaluated } \\
\text { micronuclei }\end{array}$ & $\begin{array}{l}\text { \% } \mathrm{C}^{+} \\
\left(\mathrm{no.} \mathrm{C}^{+}\right)\end{array}$ \\
\hline Control (DMSO) & $(1 \%)$ & 75 & $28(21)$ \\
Oxazepam & 200 & 100 & 47 \\
DES & 10 & 100 & 82 \\
\hline
\end{tabular}

Presence of centromeric DNA (in situ hybridization signal $\% \mathrm{C}^{+}$) in micronuclei of L5178Y cells. Cells were treated with the chemicals for $4 \mathrm{~h}$ and evaluated $5 \mathrm{~h}$ after that.

Table III. Dependence of mutation fractions on substance concentration

\begin{tabular}{lccrl}
\hline Substance & $\begin{array}{l}\text { Concentration } \\
(\mu \mathrm{g} / \mathrm{ml})\end{array}$ & CE & MnF & $\begin{array}{l}\text { Relative } \\
\mathrm{MnF}\end{array}$ \\
\hline Control (1\% DMSO) & 0 & 0.72 & 230 & 1.0 \\
EMS & 300 & 0.66 & 2120 & 9.2 \\
Oxazepam & 50 & 0.73 & 232 & 1.0 \\
& 100 & 0.54 & 332 & 1.4 \\
& 200 & 0.49 & 362 & 1.6 \\
& 250 & 0.47 & 344 & 1.5 \\
\hline
\end{tabular}

Mutation experiments were performed with mouse L5178Y cells. Each number given is the average from two independent cultures treated in one experiment. Expression time is the time between the end of substance trearment and TFT addition; expression time was $47.5 \mathrm{~h}$. A dose-response curve was also generated at an expression time of $41.5 \mathrm{~h}$ and no mutagenic response was observed. CE is cloning efficiency, $\mathrm{MnF}$ is mutation fraction and $\mathrm{RMnF}$ is the mutation fraction relative to the control.
(Schiffmann and DeBoni, 1991). Hsu et al. (1983) also showed that diazepam induced mitotic disturbances (metaphase arrest during treatment, lagging chromosomes in anaphase and multipolar spindles after treatment) in Chinese hamster cells. These authors also showed moderate aneugenic properties of diazepam. Mitotic disturbances with concomitant chromosome loss were also reported by Parry et al. (1986) and Lafi et al. (1987) in Chinese hamster cells. When we applied supravital UV microscopy according to the technique of Schiffmann and DeBoni (1991), we found an increased number of metaphases during the treatment of SHE cells with $100 \mu \mathrm{g} / \mathrm{ml}$ oxazepam. Shortly after the treatment, the cells went through mitosis, indicating the reversibility of the arrest. There was also an increased number of cells in telophase showing narrow chromatin bridges (unpublished observations).

Substances that interfere with the course of mitosis can lead to the loss of whole chromosomes (aneuploidy). To investigate whether oxazepam-induced micronuclei contained whole chromosomes, we applied CREST-staining for detection of kinetochores. About half of the oxazepam induced micronuclei stained positive in all three cell types, whereas DES yielded $\sim 80 \%$ kinetochorepositive micronuclei. Therefore, in addition to its aneugenic properties, oxazepam exerts some clastogenic activity. Because of the early appearance of these micronuclei, chromosomal breakage must occur during the first mitosis after treatment. Since it is possible that kinetochore staining may give erroneous results when the kinetochore protein is damaged (Miller et al., 1991), we hybridized mouse minor satellite DNA to mouse L5178Y cells in situ. The results verified our kinetochore data. Bonatti et al. (1992) found 65\% of diazepam induced micronuclei kinetochorepositive in three human and Chinese hamster cell types and Antoccia et al. (1991) showed the presence of kinetochores in $75 \%$ of diazepam induced micronuclei in Chinese hamster cells.

Even though diazepam also seems to have some clastogenic effect, the clastogenic effect of oxazepam accounts for half of the induced micronuclei. It should be noted that, even though the induction of micronuclei by diazepam in cultured cells in vitro had been demonstrated by two groups (Antoccia et al., 1991; Bonatti et al., 1992), the induction of micronuclei in vivo could not be demonstrated in erythrocytes of the mouse bone marrow (Adler et al., 1991). However, according to findings by Das and $\mathrm{Kar}$ (1986) micronuclei were elevated in the mouse bone marrow assay.

Oxazepam shows no consistent mutagenic activity. The mutagenicity of oxazepam has been investigated in Salmonella (Ames test) with variable results. Batzinger et al. (1978) found it to be mutagenic, whereas Balbi $e$ t al. (1980) concluded that it was non-mutagenic. We therefore investigated the mutagenic potential of this compound in mouse L5178Y cells at the tk locus. Oxazepam did not show a significant increase of mutants at any of the doses or expression times tested. In this context, an

Table IV. Dependence of mutation fractions on expression time

\begin{tabular}{|c|c|c|c|c|c|c|}
\hline \multirow{2}{*}{$\begin{array}{l}\text { Expression tume } \\
\text { (h) }\end{array}$} & \multicolumn{2}{|c|}{ Control (1\% DMSO) } & \multicolumn{2}{|c|}{ EMS $(300 \mu \mathrm{g} / \mathrm{ml})$} & \multicolumn{2}{|c|}{ Oxazepam $(200 \mu \mathrm{g} / \mathrm{ml})$} \\
\hline & $\mathrm{MnF}$ & $R M n F$ & $\mathrm{MnF}$ & $\mathrm{RMnF}$ & $\overline{\mathrm{MnF}}$ & $\mathrm{RMnF}$ \\
\hline 4 & 12 & 1.0 & 11 & 0.9 & 8 & 0.7 \\
\hline 23.5 & 23 & 1.0 & 83 & 3.7 & 23 & 1.0 \\
\hline 28 & 30 & 1.0 & 198 & 6.6 & 28 & 0.9 \\
\hline 45 & 105 & 1.0 & 1130 & 10.8 & 116 & 1.1 \\
\hline 52 & 168 & 1.0 & 1154 & 6.9 & 199 & 1.2 \\
\hline 69.5 & 478 & 1.0 & 2049 & 4.3 & 451 & 0.9 \\
\hline
\end{tabular}

See Table III for explanation. 
observation by Seredenin et al. (1986) is interesting. They reported an antimutagenic effect of benzodiazepines and attributed it to their possible radical scavenger properties.

In our studies oxazepam was found to induce genetic damage as shown by the micronucleus assay. It is not known whether the loss of chromatin material enclosed in micronuclei can result in the expression of a mutant phenotype. However, since the mouse L5178Y mutation assay could not detect this type of damage, it may be advisable to combine both assays for future genotoxicity testing.

The doses necessary for micronucleus induction are rather high for oxazepam and would be equivalent to several grams of intake per average person. The induction of mutation in mammalian cells could not be demonstrated here. However, the use of low but chronic doses of benzodiazepines may also present a risk to human health. Therefore, further investigations seem appropriate to further clarify the effect of benzodiazepines on the human organism.

\section{Acknowledgements}

This work was supported by the Hauptvertand der Gewertlichen Berufsgenossenschaften, St Augustun, FRG and by the STEP Program of the European Community, grant no. STEP-CT91-0146 (DTEE). We thank Professor H. Hoehn and Dr M.Poo (Department of Human Genetics, University of Wūrzburg, FRG) for providing AFFL cells.

\section{References}

Adler,I.-D., Kliesch,U., van Hummelen,P. and Kirsch-Volders,M. (1991) Mouse micronucleus test with known and suspect spindle poisons: results from two laboratories. Mutagenesis, 6, 47-53.

Andersson,L.C., Lebto,V.-P., Stenman,S., Badley,A. and Virtanen,I. (1981) Diazepam induces mitotic arrest at prometaphase by inhibiting centriolar separation. Nature, 291, 247-248.

Antoccia,A., Degrassi,F., Battistoni,A., Ciliutti,P. and Tanzarella,C. (1991) In vitro micronucleus test with kinetochore staining: evaluation of test performance. Mutagenesis, 6, 319-324.

Balbi,A., Muscettola,G., Staiano,N., Martire,G. and De Lorenzo,F. (1980) Psychotropic drugs: evaluation of mutagenic effect. Pharmacoh Res. Commum. 12, 423-431.

Batzinger,R.P., Ou,S.-Y.L. and Bureding,E. (1978) Antimutagenic effect of 2(3)tert-butyl-4-hydroxyanisole and of antimicrobial agents. Cancer Res., 38, 4478-4485.

Bonatti,S., Cavalieri,Z., Viaggi,S. and Abbandandolo,A. (1992) The analysis of 10 potential spindle poisons for their ability to induce CREST-positive micronuclei in human diploid fibroblasts. Mutagenesis, 7, 111-114.

Clive,D., Flamm,W.G. and Machesko,M.R. (1972) Mutagenicity of hycanthone in mammalian cells. Mutar. Res., 14, 262-264.

Das,R.K. and Kar,R.N. (1986) Genotoxic effects of three benzodiazepine tranquilizers in mouse bone marrow as revealed by the micronucleus test. Caryologia, 39, 193-198.

De la Iglesia,A., Barsoum,N., Gough,A., Mitchell,L., Martin,R.A., die Fonzo,C. and McGuire,E.J. (1981) Carcinogenesis bioassay of prazepam (Verstran) in rats and mice. Taxicol. Appl. Pharmacol., 57, 39-54.

Diwan,B.A., Rice,J.M. and Ward,J.M. (1986) Tumor-promoung activity of benzodiazepine tranquilizers, diazepam and oxazepam, in mouse liver. Carcinogenesis, 7, 789-794.

Fox,K.A. and Lahoen,R.B. (1974) Liver-cell adenomas and peliosis hepatis in mice associated with oxazepam. R. Res. Commum. Chem. Pathol. Pharmacal. 8. $481-488$.

Hartz,S.C., Heinonen,O.P., Shapiro,S., Siskind,V. and Slone,D. (1975) Antenatal exposure to meprobamate and chlordiazepoxide in relation to malformations, mental development, and childhood mortality. J. Engl. J. Med, 292, 726-728.

Hoehn,H. and Salk,D. (1982) Morphological and biochenical heterogeneity of amniotic fluid cells. Methods Cell Biol, 28, 11-34.

Hsu,T.C., Liang,J.C. and Shirley,L.R. (1983) Aneuploidy induction by mitotic arrestants: effects of diazepam or diploid Chinese hamster cells. Mutat. Res., 122, 201-209.

Husum,B., Wulf,H.C., Niebuhr,J.E. and Rasmussen,J.A. (1985) SCE in lymphocytes of patients treated with single, large doses of diazepam. Mutat. Res., 155, 71-73.

Ishidate,M.Jr., Hayashi,M., Sawada,M., Matsuoks,K., Yoshikaws,K., Ono,M. and Nakadate,M. (1978) Cytotoxicity test on medical drugs-chromosome aberration tests with Chinese hamster cells in virro. Eisei Shikenjo Hokoku. 96, 55-61.

Ishimura,K., Sawai,M., Yamamoto,K., Neda,K. and Sato,H. (1975) Sudres on the chromosomes of rat bone marrow cells treated with benzodiazepine derivatives in vio. Teratology, 12, 199.

Kanto,J.H. (1982) Use of benzodiazepines during pregnancy, labour and lactation, with particular reference to pharmacokinetic considerations. Drugs, 23, $354-380$.

Kawach,,T., Yahagi,T., Kada,T., Tazima, Y., Ishidate,M., Sakaki,M. and Sugiyama,T. (1980) Cooperative program on short-term assays for carcinogenicity in Japan. LARC Sci. Publ., 27, 323-330.

Kleineman,R.A., Brinton,L.A., Hoover,R. and Fraumeni,J.F.Jr (1984) Diazepam use and progression of breast cancer. Cancer Res., 44, 1223-1225.

Laegreid,L., Olegard,R., Walsrom,J. and Conradi,N. (1989) Teratogenic effects of benzodiazepine use during pregnancy. J. Pediatr., 114, 126-131.

Lafi,A. and Parry,J.M. (1988) A study of the induction of ancuploidy and chromosome aberrations after diazepam, medazepam, midazolam and bromazepam treatment. Mutagenesis, 1, 78.

Lafi,A., Parry,E.M. and Parry,J.M. (1987) The effects of benzodiazepines upon the fidelity of mitotic cell division in cultured Chinese hamster cells. Mutat. Res., 189, 319-332.

Matsuoloa,A., Hayashi,M. and Ishidate,M.Jr (1979) Chromosomal aberration tests in 29 chemicals combined with $S 9$ mix in vitro. Mutat. Res., 66, 277-290.

Milkovich,L. and van den Berg,B.J. (1974) Effects of prenatal meprobamate and chlordiazepoxide hydrochloride on human embryonic and fetal development. N. Engl. J. Med., 291, 1268-1271.

Miller,B.M. and Adler,I.-D. (1989) Suspect spindle poisons: induction of mitotic arrest in mouse bone marrow. Mutagenesis, 4, 208-215.

Miller,B.M., Zitzelsberger,H.F., Weier,H.U. and Adler,I.D. (1991) Classification of micromuclei in murine erythrocytes: immunofluorescem staining using CREST antibodies compared to in situ hybridization with biotinylated gamma satellite DNA. Mutagenesis, 6, 297-302.

National Toxicology Program (NTP) (1993) Taxicology and Carcinogenesis Studies of Oxazepam (CAS no. 60475-1) in Swiss Webster and B6C3FI Mice. Technical report Series No. 443. NIH publ. no. 92-3359. US Department of Health and Human Services, Public Health Service, National Institute of Health, Research Triangle Park, NC.

Parry,J.M., Parry,E.M., Calvert,R., Lafi,A. and Somers,A. (1986) The mechanisms of induction of chromosome aneuploidy as revealed by the study of aberrations of mitotic cell division. Prog. Clin Biol. Res. , 209 A, 325-332.

Preat,V., de Gerlache,J., Lans,M. and Roberfroid,M. (1987) Promoting effect of oxazepam in rat hepatocarcinogenesis. Carcinogenesis, 8, 97-100.

Remandet,B., Gouy,D., Berthe,J., Mazue,G. and Williams,G.M. (1984) Lack of unitiating or promoting activity of six benzodiazepine tranquilizers in rat liver limited bioassay monitored by histopathology and assay of liver and plasma enzymes. Fundam. Appl. Taxicol., 4, 152-163.

Robinson,R.L., Van Ryzin,R.J., Stoll,R.E., Jensen, R.D. and Bagdon,R.E. (1984) Chronic toxicity/carcinogenesis stuties of temazepam in mice and rats. Fundam. Appl. Taxicol., 4, 394-405.

Rudd,C.J., Daston,D.S. and Caspary,W.J. (1990) Spontaneous mutation rates in mammalian cells: effect of differental growth rates and phenotypic lag. Genetics, 126, 435-442.

Sasaki,M., Sugimura,M., Yoshida,A. and Abe,S. (1980) Cytogenetic effects of 60 chemicals on cultured human and Chinese hamster cells. La Kromosomo, II-20, 564-584.

Schiffmann,D. and DeBoni,U. (1991) Dislocation of chromatin elements in prophase incuced by diethylatilbestrol: a novel mechanism by which micromuclei can arise. Mutat. Res., 246, 113-122.

Schmid,W. and Staiger,G.R. (1969) Chromosome saudies on bone marrow from Chinese hamsters treated with benzodiazepine tranquilizers and cyclophosphamide. Mutat. Res., 7, 99-108.

Seredenin,S.B., Dumev,A.D., Dubovskaya,O.Yu., Korkina,L.G. and Velichkovskii,B.T. (1986) Sudies into the membrare mechanisms of chemical muragenesis and the aralysis of antimutagenous properties of some psychotropic drugs. Khim.-Farm. Zh, 12, 1425-1428.

Shannon,R.W., Fraser,G.P., Aitken,R.G. and Harper,J.R. (1972) Diazepam in preeclamptic toxaemia with special reference to its effect on the newbom infant. Br. J. Clin. Prac., 26, 271-275.

Spencer,D.S., Hines,K.C. and Caspary,W.J. (1993) An in siru protocol for measuring chemically induced mutations in mammalian cells. Mutat. Res., submitted.

Staiger,G.R. (1969) Chlordiazepoxide and diazepam: absence of effects on the chromosomes of diploid human fibroblast cells. Mutat. Res., 7, 109-115.

Staiger,G.R. (1970) Studies on the chromosomes of human lymphocytes treated with diazepam in virro. Mutat. Res., 10, 635-644.

Stoll,B.A. (1976) Psychosomatic factors and wumour growth. In Stoll,B.A. (ed.), 
Rick Factors in Breast Cancer. Heinemann Medical, London, pp. 193-203. Stopper,H., Pechan,R. and Schiffmann,D. (1992) 5-Azscytidine induces micronuclei in and morphological transformation of Syrian hamster embryo fibroblasts in the absence of unscheduled DNA synthesis. Mutar. Res., 283, $21-28$.

Torigoe, K. (1979) Sister chromatid exchange in children treated with anticomvulsant drugs. Acta Med. Biol., 27, 65-72.

Tucker,J.C. (1985) Benzodiazepines and the developing rat: a critical review. Neurosci. Biobehav. Rev., 9, 101-111.

Wong,A.K.C. and Rattner,J.B. (1988) Sequence organization and cytological localization of the minor satellite of mouse. Nucleic Acids Res., 16, $11645-11661$.

Xu,W. and Adler,I.-D. (1990) Clastogenic effects of known and suspect spindle poisons studied by chromosome analysis in mouse bone marrow cells. Mutagenesis, 5, 371-374.

Zhurkov,V.S. (1975) Investigation of the mutagenic activity of drug preparation and food additives in a culture of human lymphocytes. Sov. Genes., 11, $528-530$.

Received on March 1, 1993; accepted on April 28, 1993 